\title{
"UM HOMEM LIVRE, SÓ, RESTA NO CÁRCERE": DIÁRIO DA PRISÃO, POEMAS DE HO CHI MINH
}

\author{
"A FREE MAN, ONLY, RESTAINS IN JAIL": PRISON DIARY, POEMS FROM HO \\ $\mathrm{CHI} \mathrm{MINH}$
}

Recebido: 13/01/2021

Aprovado: $17 / 05 / 2021$

Publicado: $30 / 07 / 2021$

DOI: $10.18817 /$ rlj.v5i01.2540

\author{
Yasmeen Pereira da Cunha ${ }^{1}$ \\ https://orcid.org/0000-0003-3764-6772
}

\begin{abstract}
Resumo: O estudo de literaturas de testemunho, de maneira geral, privilegia a análise de textos literários de sobreviventes de eventos históricos catastróficos do século $\mathrm{XX}$, principalmente em relação à Segunda Guerra Mundial - no caso da Shoah - e às ditaduras latino-americanas. Partindo do alargamento dessa perspectiva, propõe-se o estudo do livro de poemas Diário da prisão, do revolucionário vietnamita Ho Chi Minh. O livro mencionado representa esteticamente a perspectiva pessoal de Ho Chi Minh, o qual foi encarcerado durante quatorze meses, em 1942, pelo Kuomintang Partido Nacionalista Chinês. Os poemas são recortes de cenas vividas pelo próprio revolucionário, mas também do dia a dia violento dos que com ele estavam presos. A importância desse breve estudo é apresentar as catástrofes do século XX como continuidades históricas, as quais afetaram não só a Europa, como também tiveram início muito antes das guerras mundiais com os processos de colonização em África e em Ásia. Por esse motivo, o testemunho de Ho Chi Minh em Diário da prisão proporciona alargamento histórico e geográfico para aqueles que foram privados de contar sua própria história.
\end{abstract}

Palavras-chave: Literatura de testemunho; Ho Chi Minh; Poemas; Revolução Vietnamita.

Abstract: In general, the study of testimonial literature privilege the analysis of literary texts of survivors of historical catastrophic events in the $20^{\text {th }}$ century, especially the ones regarding the Second World War - as the Shoah - and also the Latin-America dictatorships. Starting from this perspective, the aim of this paper is to study the book of poems The Prison Diary written by the Vietnamese revolutionary Ho Chi Minh. This book aesthetically portraits a personal perspective of Ho Chi Minh, who was kept as a prisoner for fourteen months, in 1942, by the Kuomintang - Chinese Nationalist Party. The poems are cutout of scenes experienced by the own revolutionary, but they are also of the violent daily experiences of the ones who were prisoners with him. The importance of this brief study is to present the $20^{\text {th }}$ century catastrophes as a historical continuum which affected not only Europe, but also to show that they begun long before the World Wars with the colonization process in Africa and Asia. Thus, the testimony of Ho Chi Minh in The Prison Diary provides a historical and geographical enlargement for those who were deprived of telling their own history.

Keywords: Testimonial literature; Ho Chi Minh; Poems; Vietnamese Revolution.

\footnotetext{
${ }^{1}$ Possui graduação em Letras, Licenciatura em português, pela Universidade Federal de Goiás (UFG). Tem especialização em Docência do Ensino Superior pela Faculdade Brasileira de Educação e Cultura (FABEC). Também é mestra em Estudos Literários pela UFG. Atualmente, é doutoranda pelo Programa de Pós-graduação em Letras e Linguística, da UFG, na área de concentração de Estudos Literários. É bolsista da Coordenação de Aperfeiçoamento de Pessoal de Nível Superior (CAPES). No primeiro semestre de 2021, iniciou a graduação Licenciatura em História pela Pontifícia Universidade Católica GO (PUC). E-mail: yasmeenfls@discente.ufg.br
} 


\section{Introdução}

Os estudos de literaturas de testemunho têm contribuído para rever como os processos históricos violentos foram narrados para as gerações que os sucederam. Por isso, o testemunho dos sobreviventes de massacres e de torturas é um dos pontos cruciais para a reconstrução da narrativa histórica, em especial, do século XX. Diante disso, este artigo pretende mostrar a relevância do livro de poemas Diário da prisão, do revolucionário vietnamita Ho Chi Minh, para a reconstrução histórica a partir da perspectiva do colonizado. A história do Vietnã é marcada por diversas formas de subordinação: um milênio de submissão à China, a separação do país em 1757 com o apoio francês e, finalmente, no século XIX, a consolidação da colonização francesa. As lutas por libertação nacional foram, ainda, prejudicadas pelo envolvimento americano no Vietnã que apoiou o governo autoritário de Ngo Dinh Diem, no Vietnã do Sul, na tentativa de frear os avanços do comunismo no mundo. Diário da prisão foi escrito em 1942, quando Ho Chi Minh foi preso pelo Kuomintang - Partido Nacionalista Chinês. Os poemas representam a perspectiva pessoal da vivência do prisioneiro político que diante da tortura, da fome, da doença e da humilhação pessoal, não perdeu de vista o objetivo de libertar seu país. Além disso, a apresentação do livro também convida à reflexão sobre como os eventos catastróficos do século XX são continuidades históricas do desenvolvimento do capitalismo.

\section{Literatura de testemunho: flexibilização do conceito}

Márcio Seligmann-Silva (2002), no texto “'Zeugnis' e 'Testimonio': um caso de intraduzibilidade de conceitos", apresenta sumariamente como os estudos sobre literaturas de testemunho têm sido desenvolvidos de maneira geral. Em primeiro momento, o autor comenta sobre a dificuldade de traduzir o termo alemão "Zeugnis", cuja tradução para o português é "testemunho", e "testimonio" variante no contexto latino-americano. Para Seligmann-Silva, a tradução dos conceitos depende dos eventos aos quais se referem o que, no caso da Alemanha, alude à Segunda Guerra Mundial e à Shoah, enquanto na América Latina "o ponto de partida são as experiências históricas da ditadura, da exploração econômica, da repressão às minorias étnicas e às mulheres, sendo que nos últimos anos também a perseguição aos homossexuais tem sido pesquisada" (SELIGMANN-SILVA, 2002, p. 68). Nesse 
sentido, o estudo desses textos exige percepções mais amplas, relações mais bem estabelecidas entre os processos sociais e a produção literária.

Na mesma direção, Wilbert Salgueiro (2012), no artigo "O que é literatura de testemunho (e considerações em torno de Graciliano Ramos, Alex Polari e André Du Rap)", busca definir os traços desse tipo de texto literário. O ponto de partida é diferenciar o testemunho da testemunha, uma vez que o primeiro é o relato e o segundo é a pessoa. A diferença é fundamental, já que enquanto delimita o testemunho como relato, depoimento, documento, registro etc., permite compreender que a testemunha é, por excelência, aquela que viveu a experiência. A importância desse aspecto é enfatizar a particularidade daquele que narra sua vivência, como é o caso da "literatura carcerária", termo utilizado por Salgueiro para mencionar escritores que estiveram na prisão.

Dito isso, vale mencionar o texto "A literatura de testemunho e a violência de Estado", de Valeria de Marco (2004). Para a autora, "nos últimos anos, a expressão remete sempre a uma relação entre literatura e violência" (MARCO, 2004, p. 45). principal desdobramento disso é a compreensão do testemunho como um ato político, averso à visão hegemônica da história. A principal contribuição da autora é questionar a normatização da literatura de testemunho, pois a formação literária dessas obras é permeada pelas contradições dos processos históricos e, eles mesmos, não são naturalmente padronizados. Por isso, um gênero "testemunhal”, por assim dizer, limita a leitura crítica dos livros. Especificamente aos textos literários testemunhais latinoamericanos, a autora argumenta que

\begin{abstract}
No meu entender, esta acepção do conceito de literatura de testemunho, por considerar uma grande flexibilidade quanto à forma do texto associada a uma natureza de experiências de aberto embate ideológico, abre a possibilidade de analisar uma tendência da produção literária latino-americana do século $\mathrm{XX}$ em um contexto mais amplo, que ultrapassa os limites geográficos do continente e aproxima-se à geografia mundial da barbárie, impondo a necessidade de examinar as relações entre violência, representação e formas literárias. (MARCO, 2004, p. 51).
\end{abstract}

Em síntese, é possível encontrar semelhanças entre obras literárias para que se classifiquem como "literatura de testemunho", mas é desaconselhável criar contornos rígidos para essa classificação. Pensar nas relações entre processos históricos violentos, testemunhas e formas de representações literárias não canônicas é um terreno bastante produtivo para que obras com teor testemunhal ganhem espaço 
dentro dos estudos de literatura. Tal como afirma Valéria de Marco, é preciso ultrapassar os limites geográficos e alcançar textos, também, além da Europa e da América Latina. É dentro desse panorama que Diário da prisão, de Ho Chi Minh, pode ser incluído. Apesar de os processos de repressão na América Latina terem relação direta com as experiências socialistas do século XX em África e em Ásia, figuras como Ho Chi Minh são quase desconhecidas na análise da totalidade histórica desses eventos. No Brasil, em especial, pouco se faz menção ao revolucionário vietnamita, mesmo entre a esquerda marxista. No texto "A poesia na revolução", Moniz Bandeira (1968, p. 7-8) relata:

\begin{abstract}
Magro, rosto amarelado, imberbe, cabelo na testa - este o aspecto que 0 jovem $\mathrm{Ba}$ apresentava quando desembarcou no porto do Rio de Janeiro. Trabalhava a bordo de um navio e ficaria em terra para tratamento de saúde. $\mathrm{Ba}$, ou como se notabilizou mais tarde, Ho Chi Minh habitou uma pensão no bairro de Santa Tereza. [...]. Ho Chi Minh encontrou, em 1924, Astrojildo Pereira e Rodolfo Coutinho, que buscavam reconhecimento do PCB pela Terceira Internacional.
\end{abstract}

Sua passagem ao Rio de Janeiro, o reencontro com Pereira e Coutinho em Moscou, suas lembranças da zona do mangue - "o cheiro fétido, o mercado do sexo, subproduto do capitalismo nas condições de atraso semicolonial" (BANDEIRA, 1968, p. 8) - permaneceram escondidas. Em "A análise do pensamento de Ho Chi Minh e sua formação", Pedro de Oliveira (2018, p. 21), contextualiza os aspectos biográficos do revolucionário vietnamita:

Ho Chi Minh foi o mais proeminente líder contemporâneo da Revolução Socialista do Vietnã. Viveu por 79 anos, nascido em maio de $1890 \mathrm{com}$ o nome de Nguyen Sinh Cung, na província de Kiem Lan, ao norte de seu país. Desde a juventude, engajou-se na atividade de luta contra o colonialismo e pela autodeterminação dos vietnamitas.

A formação do pensamento de Minh pode ser dividida em cinco períodos. O momento inicial abarca toda sua formação básica. Foi durante a adolescência que teve os primeiros contatos com as tradições e o patriotismo vietnamita. Além disso, "aprendeu a escrever em chinês e sofreu o forte impacto do espírito de luta anticolonialista, especialmente em relação à dominação francesa. Seus professores confucionistas, de tendência nacionalista, foram muito importantes em sua formação" (OLIVEIRA, 2018, p. 22). Nesse aspecto, vale fazer breves considerações acerca da formação do povo vietnamita. 
Etnicamente falando, segundo Paulo Fagundes Visentini (2008), no livro $A$ Revolução Vietnamita, a população do Vietnã é formada pelos imigrantes chineses e os povos thai - grupo étnico majoritário da Tailândia - que já habitavam a região. $A$ partir disso, a cultura chinesa mesclou-se ao hinduísmo. O império chinês dominou por mais de um milênio a região - chamada de Nam-Viet. Apenas em 938, o Vietnã tornou-se um Estado independente, porém, seguiram novas dominações chinesas e mongol, recuperação da independência e fases de conflitos internos entre grupos feudais. Durante o desenrolar desses fatos históricos, o budismo e o confucionismo foram introduzidos, de modo que o budismo serviu como afirmação da aristocracia fundiária, enquanto o confucionismo foi adotado como instrumento do monarca, do Estado e da adoção disciplinar, baseada na ética social, restauração da ordem, cultivo da moralidade individual e da harmonia social.

O segundo período, entre 1911 e 1920, teve início na estadia de Ho Chi Minh em Paris, quando adotou o nome de Nguyen Ái Quoc para se proteger do controle exercido pelos órgãos de segurança franceses, pois também a adolescência do revolucionário foi marcada pela repressão policial dos colonialistas franceses que tinham domínio ideológico sobre o país. Nesse período, apesar de já ter tido contato com a tradição marxista ocidental, foi quando "teve acesso ao pensamento progressista e às ideias vigentes sobre as Relações Internacionais, além do destaque que acabou dando, em sua formação, à obra de Lênin, especialmente sobre a questão colonial" (OLIVEIRA, 2018, p. 21).

O próximo período (1921 a 1930) marca o início do envolvimento de Minh com atividades políticas que culminaram com a fundação do Partido Comunista da França, o acompanhamento dos trabalhos da Internacional Comunista e a organização do Partido Comunista do Vietnã. A penúltima fase, quando adotou o nome de Ho Chi Minh ("Ho", aquele que ilumina), pode ser datada entre 1931 e 1940, a qual foi definida pelos desafios, esforços e preparativos para colocar em prática seu ideário político no Vietnã. Sabendo da pluralidade de aspectos culturais que formaram o país, vale ressaltar que "um mérito indiscutível dos quadros foi extrair do marxismo e da experiência soviética o que era essencial, retomar o nacionalismo em seus aspectos revolucionários, integrando-os e aplicando-os às condições do país" (VISENTINI, 2008, p. 26). O último período, portanto, é seu retorno ao Vietnã e sua atuação como chefe de Estado e de liderança em seu país. 
Diário da prisão foi escrito durante o período em que, ainda como Nguyen Ái Quoc, foi a Chungking, em 1942, buscar auxílio do Kuomintang - Partido Nacionalista Chinês, representante da burguesia nacional. O partido foi dirigido por Sun Yat-sen, o qual desempenhou papel de dirigente da Revolução Democrática que derrubou a dinastia Qing. Contudo, foi preso por 14 meses a mando de Chang Kai-Chek, presidente da República da China que "na tentativa de ampliar seu controle sobre a resistência, reagrupa os exilados vietnamitas na liga de Dong Minh Hoi, que exclui os comunistas" (VISENTINI, 2008, p. 32). Como mencionado anteriormente, os estudos de literaturas de testemunho analisam, em especial, os acontecimentos históricos do século XX, com foco na experiência da Alemanha nazista. Pensando, ainda, no alargamento do conceito de literatura de testemunho que propõe Valéria de Marco, assim como a definição de Seligmann-Silva, a qual destaca que os eventos históricos possuem papel fundamental na definição de uma obra como testemunhal, é preciso compreender o período da Segunda Guerra Mundial e do pós-guerra como uma totalidade de eventos complexos. Para os territórios ainda sob o jugo da colonização, a preocupação não estava concentrada no Nazismo e no Fascismo, mas em seus colonizadores.

Analisados fora da Europa como palco principal, os eventos da Segunda Guerra Mundial indicam que o século XX foi marcado também por diversas vitórias das colônias e semicolônias - o que não exclui as diversas contradições dessas vitórias, pois esses territórios foram arrasados durante anos de colonização e guerras de libertação nacional. Em relação ao Vietnã, o sucesso da Revolução Nacional Democrática e Popular foi possível graças "à aliança entre operários e camponeses, à criação de ampla frente política e nacional e de forças armadas populares, à exploração das contradições franco-japonesas e à conjuntura criada pela Guerra Mundial em um sentido amplo, que fez a França o novo 'elo mais fraco' do sistema imperialista" (VISENTINI, 2008, p. 38). Assim, o contexto da Segunda Guerra Mundial deve ser compreendido a partir dessas reflexões e das diversas formas de violência, termo recorrente nos estudos de literatura de testemunho.

\section{A violência do opressor e a reação do oprimido}

Retomando uma das vertentes predominantes do estudo da literatura de testemunho, Aimé Césaire (2020), no livro O discurso sobre o colonialismo, argumenta 
que o Holocausto foi, antes de tudo, subproduto do capitalismo como tentativa de sobrevivência. Césaire, então, considera que o homem burguês, munido do humanismo cristão do século XX, carrega consigo um Hitler sem saber e, no fundo,

o que ele não perdoa em Hitler não é o crime em si, o crime contra o homem, não é a humilhação do homem em si, é o crime contra o homem branco, é a humilhação do homem branco, é de haver aplicado à Europa os procedimentos colonialistas que atingiam até então apenas os árabes da Argélia, os coolies da Índia e os negros da África. (CÉSAIRE, 2020, p. 18, grifos do autor).

O argumento fundamental de Césaire é que os eventos catastróficos da Segunda Guerra Mundial não são, em si mesmos, individuais. Eles fazem parte do sistema econômico vigente, com as características desse mesmo sistema. O diferencial do Nazismo foi o lugar onde aconteceu, na Europa, e não a forma ou as técnicas empregadas no processo da guerra, porque elas já estavam sendo praticadas e aperfeiçoadas nos territórios que passaram por processos de colonização. A colonização é um ato de guerra que desciviliza o colonizador e

\begin{abstract}
para brutalizá-lo no sentido apropriado da palavra, degradá-lo, despertá-lo para instintos soterrados, cobiça, violência, ódio racial, relativismo moral, e mostrar que toda vez que no Vietnã há uma cabeça decepada e um olho furado, e na França se aceita isso, uma menina é estuprada, e na França se aceita isso, há um acréscimo de peso morto da civilização, ocorre uma regressão universal, uma gangrena se instala, um foco de infecção se espalha, e que no final de todos esses tratados violados, todas essas mentiras propagadas, todas essas expedições punitivas toleradas, todos aqueles prisioneiros amarrados e "interrogados", todos esses patriotas torturados, no final desse orgulho racial estimulado, dessa jactância propagada, existe o veneno incutido nas veias da Europa, e o processo lento, mas seguro, do asselvajamento do continente. (CÉSAIRE, 2020, p. 17).
\end{abstract}

As duas guerras mundiais, assim como as ditaduras na América Latina, são continuidades históricas geradas a partir dos interesses do capitalismo. A civilização capitalista que legitima a colonização já é, portanto, uma civilização doente e moralmente atingida e, por consequência, negando acontecimentos históricos não direcionados ao homem branco, gerará outros homens como Adolf Hitler. Césaire, nascido em Basse-Pointe, comuna francesa situada na Martinica, reconhece os atos bárbaros da colonização francesa, tal como os vietnamitas. Durante a resistência fascista e anticolonial no Vietnã,

A repressão francesa foi brutal, incluindo bombardeios aéreos, queima de aldeias e massacres indiscriminados. O esmagamento do levante deixou um saldo de milhares de mortos. Longas filas de prisioneiros ligados por um 
arame que lhes atravessara as mãos ou a barriga foram conduzidas no litoral e jogadas ao mar. (VISENTINI, 2008, p. 29).

Seguindo o mesmo raciocínio, Frantz Fanon (1968), em Os condenados da terra, argumenta que a colonização é sempre um ato violento. Assim como Césaire, Fanon considera o fascismo uma versão europeia da colonização, ou seja, a colonização nos próprios países colonizadores. Dito isso, parece fundamental saber distinguir as formas de violência praticadas ao longo da história do desenvolvimento capitalista, no sentido de que individualizar catástrofes oriundas de guerras ou processos ditatoriais não gera o entendimento desses conflitos como continuidades históricas. Fanon explica que existe uma "violência atmosférica" que é percebida pelo colonizado e, quando ele resolve revidar em busca de sua libertação, incentiva outros povos colonizados a buscar o mesmo objetivo. Sobre isso, Fanon (1968, p. 53-54) diz:

\begin{abstract}
O povo colonizado não está só. À despeito dos esforços do colonialismo, suas fronteiras permanecem permeáveis às novidades, aos ecos. Ele descobre que a violência é atmosférica, escala aqui e ali, e aqui e ali derrota o regime colonial. Essa violência triunfante desempenha um papel não somente informador como também operativo para o colonizado. A grande vitória do povo vietnamita em Dien-Bien-Phu não é mais, rigorosamente falando, uma vitória vietnamita. A partir de julho de 1954, o problema proposto aos povos coloniais passou a ser o seguinte: "Que é preciso para fazer um Dien-BienPhu? Como se há de proceder?". Da possibilidade desse Dien-Bien-Phu nenhum colonizado podia duvidar mais.
\end{abstract}

Dien Bien Phu é um "lugarejo perdido nos confins da fronteira montanhosa" (VISENTINI, 2008, p. 50) entre Vietnã e Laos em que, após vários dias de resistência, 16 mil soldados de elite renderam-se ao Viet Minh - movimento de libertação nacional liderado por Ho Chi Minh. Contudo, mesmo após criação dos Acordos de Genebra em 20 de julho de 1954, em que fica estabelecida a separação temporária do Vietnã para cessar fogo, fazendo com que as tropas do Viet Minh saíssem da parte Sul do país,

[...] iniciaram-se os massacres camponeses nas chamadas "campanhas de denúncias de comunistas". Centenas de aldeias queimadas, milhares de pessoas assassinadas coletivamente e prisioneiros colocados nas famosas "jaulas para tigres". Desde o início, os comunistas denunciaram a violação dos Acordos de Genebra sem reagir: não apenas os presos políticos não haviam sido libertados, como os simpatizantes do Viet Minh estavam sendo mortos ou aprisionados (e Ho, que havia libertado os pró-franceses que foram para o Sul, era acusado de terrorista...). Ho Chi Minh tentou desesperadamente cumprir os acordos, tal como fizera em 1945-1946. E, como daquela vez, foi a agressão da outra parte que levou ao reinício da guerra. (VISENTINI, 2008, p. 54). 
Quando, numa guerra, um dos adversários resolve praticar atos não violentos como estratégia de término do conflito, está em desvantagem. É nesse sentido que Fanon (1968, p. 46-47) argumenta contra o discurso da "não violência":

\begin{abstract}
Mas é claro que, nos países coloniais, só o campesinato é revolucionário. Nada tem a perder e tem tudo a ganhar. O camponês, o desclassificado, o faminto é o explorado que mais depressa descobre que só a violência compensa. Para ele, não há compromisso, não há possibilidade de arranjo. A colonização - ou a descolonização - trata-se simplesmente de uma relação de forças. $O$ explorado logo percebe que sua libertação pressupõe todos os meios e desde logo a força. [...] o colonialismo não é uma máquina de pensar, não é um corpo dotado de razão. É a violência em estado bruto e só pode inclinar-se diante de violência maior.
\end{abstract}

Compreendendo que para vencer a guerra os vietnamitas não poderiam confiar no cumprimento de acordos, é que uma pequena nação camponesa - expressão nacional de uma revolução social, com larga tradição de resistência nacional e capaz de fazer sacrifícios sobre-humanos - derrotou uma superpotência militar, industrial e tecnológica. Continuando seu argumento, Fanon questiona: o que é, na realidade, a violência revolucionária? Para o autor, reagir contra o genocídio dos povos colonizados é uma forma de mediação, em que o homem colonizado liberta-se na e pela violência. Essa reação deve ser proporcional à violência exercida pelo regime colonialista. Em relação ao resultado do emprego da força máxima pelos oprimidos, Fanon (1968, p. 71) argumenta

[...] o povo colonizado não mantém contabilidade. Registra os vazios enormes feitos em suas fileiras como uma espécie de mal necessário. Uma vez que também decidiu responder com a violência, admite todas as consequências dessa decisão. Apenas exige que não lhe peçam para manter a contabilidade para os outros.

O emprego da violência é uma decisão que se mostra como única alternativa de barrar o domínio colonial. Desse modo, a continuidade do colonialismo no século XX, com o objetivo de dominar territórios de influência econômica, obriga o colonizado a sempre estar preparado para atos violentos. Como último apontamento, vale ressaltar que as experiências de libertação nacional também têm como expectativa retomar o lugar prioritário do colonizado de poder contar sua própria história:

$\mathrm{O}$ colono faz a história e sabe que faz. E porque se refere constantemente à história de sua metrópole, indica de modo claro que ele é aqui e ali o prolongamento dessa metrópole. A história que escreve não é portanto a história da região por ele saqueada, mas a história de sua nação no território explorado, violado, esfaimado. A imobilidade a que está condenado o 
colonizado só pode ter fim se o colonizado se dispuser a pôr termo à história da colonização, à história da pilhagem, para criar a história da nação, a história da descolonização. (FANON, 1968, p. 38).

Fanon não desconsidera os danos físicos e psicológicos do processo violento de descolonização, porém, instrui às massas colonizadas a agirem como protagonistas da luta de libertação por seus territórios e saber reconstruir sua história com os aspectos positivos e negativos desse processo. Essa lógica é também representativa de Ho Chi Minh, que convida a nação vietnamita a retomar seu território e sua história.

\section{Diário da prisão}

Em "Poesia na revolução", artigo já mencionado, Moniz Bandeira apresenta uma série de nomes de revolucionários que se dedicaram a refletir sobre literatura e, inclusive, escreveram textos literários, sendo eles: Marx, Trotsky, Mao Zedong, Patrice Lumumba, entre outros. Porém, a potência criativa desses autores, posteriormente, foi concentrada no estudo e na prática objetiva dos processos revolucionários. No caso de Ho Chi Minh, "se a prática do revolucionário traduz o espírito do poeta, a obra do poeta explica o espírito revolucionário. Não se pode compreendê-lo como combatente sem conhecê-lo como artista" (BANDEIRA, 1968, p. 12). A afirmação de Bandeira é pertinente, porém, é necessário compreender como Minh se apropriou do fazer poético ao longo de sua trajetória. Diário da prisão é a perspectiva pessoal, a experiência vivida, do indivíduo que está encarcerado. Sem dúvida, a motivação da escrita do livro é indissociável da sua prática revolucionária - vale lembrar que seu cárcere teve motivações políticas. Contudo, o revolucionário vietnamita entendia que a elaboração de poemas também tinha função pedagógica. No texto "Nacionalismo revolucionário: teoria e prática", Minh (1980, p. 257) instrui que, para a transformação ideológica e o fortalecimento do espírito do Partido, é preciso ter atitudes corretas, sendo elas:

[...] ser modesto e franco. O nível de compreensão ideológica no nosso Partido é geralmente baixo; ninguém pode vangloriar-se de ser bom nisso. [...] Considerar o estudo, voluntária e conscientemente, como uma tarefa a ser executada a qualquer custo por um quadro revolucionário; trabalhar ativamente e por iniciativa própria para cumprir o plano de estudo, enfrentando eventuais dificuldades com diligência e esforço persistente. [...] Ajudar uns aos outros no estudo, conduzir à autocrítica sincera com vontade 
de ser solidário, com o objetivo de formar uma nova solidariedade sobre bases novas.

Percebe-se, com esse trecho, que Ho Chi Minh tinha grande preocupação com a formação política dos membros do Partido, pois o nível de alfabetismo do povo vietnamita era alto. Desse modo, com objetivo de auxiliar a memorização os ideais revolucionários, as diretrizes do Partido eram transformadas em poemas. Em 25 de maio de 1922, Minh publicou um escrito que tinha como propósito divulgar doze recomendações às pessoas do exército, da administração e das organizações de massa. São elas:

Seis proibições: 1 - Não danificar de maneira alguma a terra e as plantas ou as casas e os bens das pessoas; 2- Não insistir em comprar ou tomar emprestado o que as pessoas não desejam vender ou emprestar; 3- Não levar galinhas vivas para as casas das pessoas nas montanhas; 4- Nunca faltar com a palavra; 5- Não ofender a fé e os costumes das pessoas (como mentir ante o altar, levantar os pés mais alto que o coração, tocar música em casa); 6- Não fazer ou falar coisas que façam as pessoas pensarem que as desprezamos. Seis permissões: 1- Ajudar as pessoas em suas tarefas diárias (colher, juntar lenha, carregar água, costurar, etc.); 2- Sempre que possível comprar mercadorias para aqueles que vivem longe dos mercados (faca, sal, agulhas, fios, canetas, papel, etc.); 3- Nas horas livres, contar pequenas histórias divertidas e simples úteis à resistência, mas não revelar segredos; 4- Ensinar à população a escrita nacional e a higiene básica; 5- Estudar os costumes de cada região para se familiarizar com eles, de forma a criar uma atmosfera de simpatia no início e então explicar às pessoas gradualmente que diminuam suas superstições; 6 - Mostrar às pessoas que você é correto, diligente e disciplinado. (MINH, 2018, p. 69)

Após isso, Ho Chi Minh escreveu um poema cujo título é "Um poema estimulante"

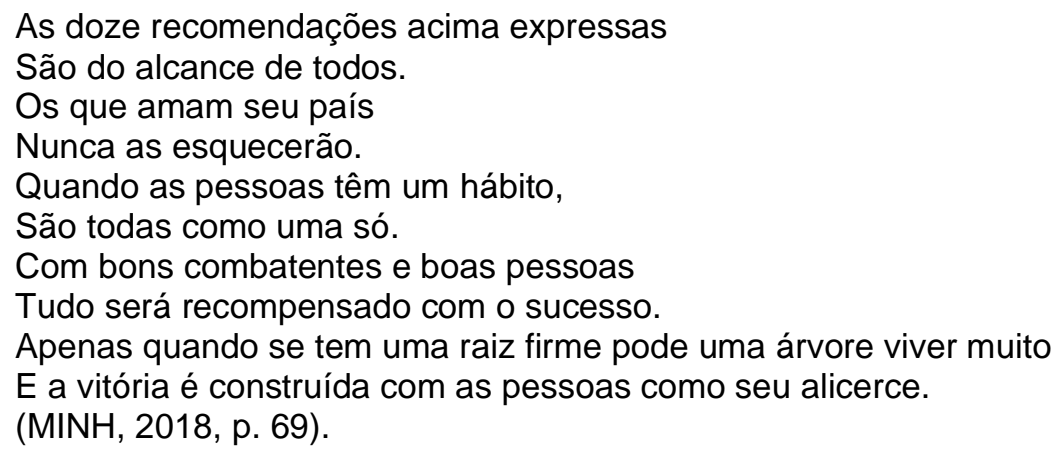

O poema acima tem como propósito a divulgação das ideias do Partido, a postura correta que os militantes comunistas devem adotar. Diário da prisão não é um livro de agitação e propaganda, tal como é visível no poema "Em primeira mão": 
Versos jamais me apaixonaram tanto.

Mas, sem nada a fazer prisioneiro, distraio os dias, que são longos, rimo enquanto espero ver a liberdade.

(MINH, 1968, p. 19).

Pelo conteúdo do poema, é visível que o próprio Ho Chi Minh não encarava os poemas que escrevia para disseminar as ideias do Partido como escrita artística. Na cadeia, contudo, "rimo/ enquanto espero ver a liberdade". A produção poética com finalidade artística para o revolucionário vietnamita é uma maneira de sobreviver ao cárcere. Antes de analisar propriamente os poemas, algumas informações sobre a tradução são necessárias. Originalmente, Ho Chi Minh escreveu o livro em chinês médio, utilizado entre os séculos VII e X, para que não descobrissem sua identidade. A tradução do vietnamita para o francês, Carnet de prison, feita por Phan Nhuam, merece alguns apontamentos, assim como a tradução do francês para o português, de Coema Simões e Moniz Bandeira.

Há poucas informações disponíveis sobre Phan Nhuam, porém, a nota introdutória de Carnet de prison, livro publicado em Hanoi em 1994, dá indícios de que o tradutor era chinês: "Um dia, em um momento de boa receptividade, peguei um texto literário em vietnamita que eu conhecia bem e traduzi-o para o francês que me é familiar" e "[...] a tradução do Carnet de prison de Ho Chi Minh, escrito nas condições que sabemos do chinês clássico, língua que filho de letrados, eu sinto intimamente" (NHUAM, 1994, p. 253-257). Mais do que uma nota de tradução, Phan Nhuam relata o processo de tradução não apenas em seu sentido estrutural, mas as experiências de um tradutor que, na tentativa de chegar à vivência daquele que narrou sua história, busca reviver as impressões do cárcere. A maior parte dos poemas de Ho Chi Minh foram traduzidas na prisão de la Santé, em tardes de chuva e neblina, para criar um ambiente parecido às condições do revolucionário vietnamita na prisão. Porém, ressalta que

Parece-me difícil para um tradutor se contentar apenas com os recursos da imaginação, por exemplo, imaginar a tristeza do chuvisco no ExtremoOriente, se tão jovem não marchou sob a estrada mandarina entre duas cidades, sob essa chuva impalpável que penetra o corpo e atravessa a alma. Eu fiz um chamado pelas minhas lembranças de criança para recriar a atmosfera de fundo e para realizar as melhores condições de ambiente. Acreditei que os poemas de prisão ganhariam mais ao serem lidos e traduzidos na prisão. (NHUAM, 1994, p. 258). 
Quanto aos aspectos estruturais, Nhuam partiu de um estudo comparativo. O tradutor afirma que o método filológico é incapaz de reconhecer duas maneiras antagônicas de se exprimir, como a vietnamita e a francesa - além também da chinesa - por isso, a comparação é baseada nos materiais comparativos entre as relações de pensamentos, tais como: a palavra e seu ambiente; as cargas afetivas que envolvem a natureza e as palavras; a frase e o encadeamento de ideias; as abstrações de cada etapa da civilização; diferenças geográficas e sociais, entre outros. Assim,

Esse estudo comparativo me permitiu ver através da refração das palavras e das reviravoltas do caminho do pensamento dos poetas clássicos vietnamitas, pensamento que desafia os métodos de análise e de investigação vigentes. O pensamento poético extremo-oriental recoloca em perspectiva, ou para empregar a expressão imagética de um grande poeta e tradutor do século XVIII, Phan Huy Ich, a veia subterrânea que corre sob as palavras, le van mach, uma vez reencontrado, a dificuldade maior é levantada. Não resta mais do que implementar os meios poéticos de outra língua para reproduzir a imagem, a impressão ou o sentimento à sua plausível humanidade. (NHUAM, 1994, p. 256).

Os procedimentos de tradução do francês para o português, feita por Coema Simões e Moniz Bandeira, alertam também para o fato de que não é possível ler os poemas de Ho Chi Minh com os padrões estéticos ocidentais. Moniz Bandeira (1968, p. 14) aponta que "Ho Chi Minh, através das contradições que joga em cada verso, imprime-lhe um conteúdo ético [...]. A sátira transparece no drama. A esperança toma lugar no desespero. O otimismo aponta a tragédia". O sarcasmo e a ironia, transparecidos no drama, podem ser vistos nos trechos do poema "A mulher visita o marido preso": "Ele/ Detrás das grades./ Ela/ diante. Tão próximos: uma polegada./ E tão distantes: o céu da terra" (MINH, 1968, p. 29), bem como no poema "Estória para rir": "A moradia oficial, o arroz do Estado,/ a guarda se reveza a cada passo./ Horas de ócio, passeios à vontade./ Não acham muita honra para um homem? (MINH, 1968, p. 37). Em "A mulher visita o marido preso", Ho Chi Minh enxerga a ironia da proximidade e, ao mesmo tempo, da distância entre marido e mulher, proporcionada pela condição de prisioneiro do homem. A ironia, nesse caso, reside na contradição espacial entre duas pessoas separadas pelo Estado chinês. Ao contrário, em "Estória para rir", o vietnamita ridiculariza a figura do prisioneiro diante das autoridades, uma sátira mordaz diante do questionamento feito no último verso do poema.

O sentimento de um prisioneiro que sofre nuances a cada momento é identificável em todo o livro. O poema inicial, que também se chama "Diário da prisão", 
apresenta a figura de um preso político que compreende a natureza da sua prisão, bem como seu propósito: "Aqui teu corpo está preso na cela./ Teu espírito não. Ele está livre./ Se queres continuar tua missão,/ deves manter elevado o teu moral" (MINH, 1968, p. 19). O conteúdo do poema é bastante semelhante às preocupações das lideranças dos movimentos de resistência do sistema colonial no Vietnã que, para evitar isolar o movimento, organizavam marchas para o Sul do país, desencadeando a "propaganda armada", em busca de demonstração de força, "mas só combater o inimigo quando obrigado. Tal política elevava o moral do povo e criava problemas para o inimigo" (VISENTINI, 2008, p. 31). Enquanto mantivesse seu moral elevado, Ho Chi Minh via no desespero da prisão a esperança da vitória vietnamita. Outros poemas, contudo, são representações mais diretas da degradação sofrida por Ho Chi Minh durante seus 14 meses presos. Um deles é "Na estrada... Os guardas carregavam um porco" (MINH, 1968, p. 38):

\footnotetext{
Carregando um leitão, os guardas me puxavam.

Vai nos braços um porco, o homem na coleira. Um porco vale mais. É baixo o preço do homem quando não se pode usar sua liberdade.

Entre mil aflições, centenas de infortúnios, perder a liberdade é o pior que existe.

Quando cada atitude e cada gesto espreitam, sois um cavalo, um boi que qualquer um maneja.
}

O poema acima não é expresso pelo recurso estilístico do sarcasmo ou da ironia do prisioneiro, mas da humilhação de ser menos importante do que um porco por ter sido privado de sua liberdade. O testemunho de Ho Chi Minh é o do homem que, durante toda a vida, buscou a liberdade para seu povo mas, naquele momento, nada mais era do que um cavalo ou um boi "que qualquer um maneja". Ao contrário do poema "Diário da prisão", o sentimento contraditório da humilhação deixa em suspenso o cumprimento de sua responsabilidade como revolucionário vietnamita. Mesmo com ideários consolidados durante mais ou menos 30 anos de formação, o ambiente degradante do cárcere enfraquece seu moral. Outro poema que testemunha o indivíduo Nguyen Sinh Cung, nome de batismo de Ho Chi Minh, é "Noite em Long Ts'iuen" (MINH, 1968, p. 27):

Correm durante o dia meus cavalos rápidos.

Como um frango no espeto. Eu à noite me sinto.

O frio aproxima-se, os piolhos traiçoeiros.

Mas com o verdelhão por sorte canta o dia. 
Quando o prisioneiro faz menção aos seus "cavalos rápidos" está falando de suas próprias pernas que, de acordo com uma das notas de tradução da edição vietnamita, Ho Chi Minh perfazia "53 quilômetros durante o dia, para velá-las à noite, metidas em ferros, como frango no espeto ou, mais exatamente: como frango em cinco temperos, versão chinesa do frango no espeto" (MINH, 1968, p. 27). Para melhor representação do instrumento de tortura, o "frango no espeto" é semelhante ao paude-arara, tão conhecido durante a Ditadura Empresarial-Militar no Brasil. A parte do verso "Eu à noite me sinto" particulariza a vivência do prisioneiro diante às torturas que pioram com o frio da noite e os "piolhos traiçoeiros". O último verso refere-se ao "verdelhão" - espécie de pássaro - que anuncia o dia. Contudo, a referência ao pássaro é mais melancólica do que esperançosa, já que as torturas na prisão recomeçariam ao amanhecer. As violências diárias não se resumiam, no entanto, à violência física deliberadamente praticada pelas autoridades, mas também às consequências psicológicas decorrentes da tortura. Isso pode ser visto no poema "Insônia" (MINH, 1968, p. 43):

Uma noite sem dormir. Duas noites. Três noites. Impossível dormir! Agito-me, angustiado.

Quarta noite. Quinta noite... Será sonho? Será vigília?

Cinco pontas de uma estrela enrolam meus pensamentos.

A estrela de cinco pontas, símbolo da bandeira de resistência vietnamita, ocupa o pensamento do prisioneiro que se vê impedido de cumprir o dever que ele mesmo se propôs. A angústia, sentimento que não aparece em seus poemas de formação política, ganha expressividade, pois é a experiência do indivíduo e não do revolucionário - muito embora essa separação não exista na complexa subjetividade de Ho Chi Minh - que se manifesta. O poeta deixa que os sentimentos mais íntimos, menos favoráveis ao fervor revolucionário, ganhem espaço, porque o encarceramento impede-o de seguir seu propósito. As nuances dos sentimentos de Ho Chi Minh enquanto prisioneiro também são vistas no poema "Quatro meses, já" (MINH, 1968, p. 53):

\footnotetext{
"Um dia encarcerado mil anos lá fora". Não é vã palavra este provérbio é antigo. Quatro meses na cela, destruíram meu corpo
} 
mais que dez anos de vida.

Quatro meses de fome,

quatro meses de insônia,

sem mudar de roupa,

sem poder me lavar.

Abandonou-me um dente,

cabelos branquearam,

negro, magro, faminto,

vestido de sarnas e feridas.

Mas, paciente sou,

duro, rijo,

sem recuar um palmo.

Materialmente miserável,

o moral, firme.

Quatro, dos quatorze meses em que Ho Chi Minh ficou preso, tornou-o materialmente miserável, mas manteve firme os ideais da luta anticolonialista. Diário da prisão, mesmo com todas as barreiras linguísticas, conservou a vivência traumática do cárcere, mas também o que manteve o moral de Ho Chi Minh resistente: A luta anticolonialista no Vietnã. Ho Chi Minh viveu a Revolução Anticolonial, a implantação do socialismo no Vietnã do Norte e a guerra civil no Sul e, até 1969, ano de sua morte, lutou na Guerra de Libertação Nacional. Sua prisão faz parte de uma trajetória pessoal, mas também da nação pela qual lutou. A história do povo vietnamita está intimamente ligada os sentimentos mais particulares de Nguyen Sinh Cung e, por isso, merece ser contada.

\section{Considerações finais}

Retomando o argumento de Césaire sobre o embrutecimento do colonizador que gera as situações mais degradantes possíveis aos colonizados, é importante dizer que o custo de qualquer guerra para, como Césaire diz, "o homem em si", é negativo para ambos os lados. Sobre isso, Visentini (2008, p. 92-93) informa:

[...] dos 2,7 milhões de norte-americanos que passaram pelo Vietnã, 60 mil morreram e 300 mil foram feridos, sendo que a maior parte destes ficou inválida. Dezenas de hospitais foram construídos nos Estados Unidos para tratamento mental de soldados e recuperação de milhares de viciados. A dificuldade de readaptação pode ser exemplificada com os episódios de veteranos do Vietnã que entraram em alguma lanchonete e matam dezenas de pessoas desconhecidas [...]. Se o preço pago pela grande potência industrial fora elevado, 0 da pequena nação agrária superava-o qualitativamente. Quase $30 \%$ da superfície arável do país fora inutilizada por bombas, napalm e, sobretudo, pelas armas químicas. Trezentas mil toneladas de bombas não explodidas continuam causando vítimas até hoje. 
O objetivo norte-americano era neutralizar as revoluções no Terceiro Mundo, reforçar sua hegemonia com seus aliados, além de desenvolver a indústria armamentista que estimulava a economia dos Estados Unidos. Não importava as mortes dos vietnamitas, bem como a de seus próprios soldados que, viciados em drogas devido aos traumas, voltaram para casa após motins que levaram ao assassinato de oficiais e suboficiais norte-americanos. Com o fim do bloco soviético e a forte propaganda anticomunista, os vencedores contaram a história das experiências socialistas do século XX como ditaduras sangrentas. Diário da prisão exige que o leitor busque ir além da história oficial para que os eventos catastróficos do século $X X$ sejam assimilados como continuidades históricas de povos violentados há séculos. Nesse sentido, este artigo é uma apresentação modesta do livro de poemas de Ho Chi Minh, testemunho de sua militância, que altera a perspectiva hegemônica da história.

\section{Referências Bibliográficas:}

BANDEIRA, Moniz. Poesia na Revolução. In: Ho Chi Minh. Poemas do cárcere: Diário da prisão. Rio de Janeiro, Guanabara, 1968. p. 7-18.

CÉSAIRE, Aimé. O discurso sobre o colonialismo. São Paulo: Veneta, 2020.

FANON, Frantz. Os condenados da terra. Rio de Janeiro: Editora Civilização Brasileira, 1968.

MARCO, Valeria de. A literatura de testemunho e a violência de Estado. In: Lua Nova - Revista de cultura e política, São Paulo, v. 62, p. 45-68, 2004.

MINH, Ho Chi. Ho Chi Minh: Escritos 1919-1969. São Paulo: Ciências Revolucionárias: 2018.

. Nacionalismo revolucionário: teoria e prática. In: Jaime Pinsky. Questão nacional e marxismo. São Paulo: Editoria Braziliense, 1980. p. 255-258.

NHUAM, Phan. Note de traduction. In: Ho Chi Minh. Carnet de prison. Hanoi: Editions Thê Giói, 1994. p. 253-259.

OLIVEIRA, Pedro de. A análise do pensamento de Ho Chi Minh e sua formação. In: Ho Chi Minh: Escritos 1919-1969. São Paulo: Ciências Revolucionárias, 2018. p. 2160. 
SALGUEIRO, Wilberth. O que é literatura de testemunho (e considerações em torno de Graciliano Ramos, Alex Polari e André Du Rap). In: Revista Matraga, Rio de Janeiro, v. 19, n. 31, p. 284-303, 2012.

SELIGMANN-SILVA, Márcio. "Zeugnis" e "Testimonio": um caso de intraduzibilidade de conceitos. In: Pandaemonium germanicum, São Paulo: DAAD, p. 67-83, 2002.

VISENTINI, Paulo Fagundes. A Revolução Vietnamita: da libertação nacional ao socialismo. São Paulo: Editora UNESP, 2008. 